Yüzüncü Yil Üniversitesi
Tarim Bilimleri Dergisi

Araştırma Makalesi (Research Article)

The Effects of Farmyard Manure and Green Manure Applications on Some Soil Physical Properties Metin MÜJDECİ ${ }^{* 1}$, Azra Cevahir DEMIRCiOĞLU', Pelin ALABOZ ${ }^{3}$

1,2,3 Isparta University of Applied Sciences, Faculty of Agriculture, Department of Soil Science and Plant Nutrition, Isparta, Turkey.

${ }^{1}$ https://orcid.org/0000-0002-0579-4538 ${ }^{2}$ https://orcid.org/0000-0003-2968-7013 ${ }^{3}$ https://orcid.org/0000-0001-7345-938X

*Sorumlu yazar e-posta: metinmujdeci@isparta.edu.tr

\section{Article Info}

Received: 03.10.2019

Accepted: 12.02.2020

Online Published 31.03.2020

DOI: 10.29133 /yyutbd.628921

Keywords

Farmyard manure,

Green manure,

Soil physical properties.

\begin{abstract}
In this research was carried out to determine the effects of farmyard manure and green manure applications on some soil physical properties in a three yearly organic vegetable cultivation field. The effects of control (C), farmyard manure (FYM) (35 tha-1) and green manure (GM) applications on some soil physical properties (soil water characteristics $(0.001,0.1,0.33,1,5,10$ and 15 bars), available water content, porosity and bulk density) were investigated in 0 10 and $10-20 \mathrm{~cm}$ soil depths for two years. At all tension values, the highest volumetric soil water contents were obtained for FYM application and the lowest ones for $\mathrm{C}$ treatment. The highest total porosity along with macro and micro porosity were found in the FYM application and the lowest ones were found in the $\mathrm{C}$ application. The available water content was the highest in the GM application and the lowest in the $\mathrm{C}$ application. In addition, the highest bulk density was found in C application and the lowest bulk density was found in FYM application. These results showed that the effects of different organic material applications on soil physical properties are important.
\end{abstract}

\title{
Çiftlik Gübresi ve Yeşil Gübre Uygulamalarının Bazı Toprak Fiziksel Özelliklerine Etkileri
}

\section{Makale Bilgileri}

Geliş: 03.10.2019

Kabul: 12.02 .2020

Online Yayınlanma 31.03.2020

DOI: $10.29133 /$ yyutbd.628921

\section{Anahtar kelimeler}

Çiftlik gübresi,

Yeşil gübre,

Toprak fiziksel özellikleri.
Öz: Bu araştırma, üç yll boyunca organik sebze yetiştiriciliği yapılan bir arazide çiftlik gübresi ve yeşil gübre uygulamalarının bazı toprak fiziksel özellikleri üzerine etkilerini belirlemek üzere yürütülmüştür. Kontrol $(\mathrm{K})$, çiftlik gübresi (ÇG) (35 ton ha-1) ve yeşil gübre (YG) uygulamalarının 0-10 ve 10-20 cm toprak derinlikleri için bazı toprak fiziksel özellikleri (toprak su karakteristikleri (0.001, $0.1,0.33,1,5,10$ ve 15 bar), yarayışlı su içeriği, gözeneklilik ve hacim ağırlığı) üzerine etkileri 2 yıl süresince incelenmiştir. Araştırmada tüm tansiyon değerlerindeki, en yüksek hacimsel toprak su içeriği ÇG uygulamasında, en düşük değerler ise $\mathrm{K}$ uygulamasında elde edilmiştir. En yüksek toplam gözeneklilik ile makro ve mikro gözenek hacmi ÇG uygulamasında, en düşük değerler ise $\mathrm{K}$ uygulamasında bulunmuştur. Yarayışlı su içeriği ise en yüksek YG uygulamasında en düşük ise $\mathrm{K}$ uygulamasında elde edilmiştir. Ayrıca en yüksek hacim ağırlığ $\mathrm{K}$ uygulamasında, en düşük hacim ağırlı̆̆ı ise ÇG uygulamasında bulunmuştur. $\mathrm{Bu}$ sonuçlar, farklı organik materyal uygulamalarının toprak fiziksel özellikleri üzerine etkilerinin önemli olduğunu göstermiştir.

This study was financially supported by the Scientific Research Foundation of Süleyman Demirel University as a MSc thesis with project number of 3093-YL-12. The paper was partially presented at the $8^{\text {th }}$ International Conference of Strategic Research on Scientific Studies and Education, Vienna/Austria and published as an abstract. 


\section{Introduction}

Soil organic matter is key tool to improve soil structure and sustainable soil fertility. Organic matter content of Turkish soils is inadequate due to the effect of climate and agricultural use for many years (Eyüpoğlu, 1999; Tümsavaş, 2003; Turan et al., 2010; Bellitürk, 2011). The applied organic materials affect many physical, chemical and biological properties of soils. Depending on the decomposition and humification degree of the applied material, it significantly affects the soil physical properties. Organic matter can able to form and strengthen of aggregate structure in soil by stimulating the organic activity. This is especially important for silt, loam and clay soils because it improves the air and water budget of soils (Özbek et al., 1995). Air-water relations are very important for maintaining the productivity of soils. In a typical soil, soil air should contain at least $10 \%$ oxygen and at most $5 \%$ carbon dioxide (Rowell, 1996) and soil water content should support plant growth. As the degree of aggregation increases, the number of micro and macro pores and the total porosity increases, whereas the bulk density decreases (Karaman et al., 2007). Consequently, soil aeration and water holding capacity can be improved (Haynes and Naidu, 1998) upon organic matter incorporation. The effects of various organic materials (manure, wheat straw, garbage compost, chicken manure, green manure, bio solid etc.) on some physical and chemical properties of soils have been investigated by many researchers (Alagöz et al., 2006; Gulser and Candemir, 2012; Mujdeci and Uzumcu, 2017; Mujdeci et al., 2017a; Alaboz et al., 2017a; Altıkat et al., 2018). However, each of these materials has different effects on the physical, chemical and biological properties of soils depending on the nature and properties of the materials.

Turkey is not a water-rich country and the distribution of precipitation is highly irregular. The fertility is closely related not only to nutrient content but also to physical properties of soils. Organic matter, however can improve both of these properties towards maximize the yield. For optimum crop yield, estimating the required irrigation water from the field capacity, wilting point and evapotranspration data could be an effective irrigation management practice.

Therefore, the effects of two organic materials, farmyard manure and green manure, having different nature were investigated on some soil physical properties (soil water characteristics $(0.001$, $0.1,0.33,1,5,10$ and 15 bars), available water content, porosity and bulk density).

\section{Material and Methods}

This study was conducted at the experimental field of Agricultural Research Centre of Suleyman Demirel University. The field experiment (2010-2013) was set up in completely randomised design in triplicates. Organic vegetables (Tomatoes in 2010, cowpeas in 2011 and 2012) were grown in the plots treated with two different organic fertilizers (farmyard manure (FYM) and green manure (GM)) and control (C) without any organic and/or inorganic fertiliser. 35 t ha $^{-1}$ of FYM consisting of 45\% dry matter was yearly incorporated into the soils and thoroughly mixed into top soil $(0-15 \mathrm{~cm})$ by means of rototiller on $21^{\text {st }}$ of May to $7^{\text {th }}$ of June depending on the year. Common vetch (Vicia sativa L.) at flowering stage was incorporated into the soil simultaneously with the FYM treatment by chisel (0-25 $\mathrm{cm})$ and rototiller $(0-15 \mathrm{~cm})$, respectively.

Some physical and chemical properties of the experiment soil and FYM were given in Table 1 (Üzümcü, 2016). Disturbed and undisturbed soil samples were taken (10.03.2012, 08.03.2013) from 0$10 \mathrm{~cm}$ and $10-20 \mathrm{~cm}$ depths.

Table 1. Some physical and chemical properties of experiment soil and FYM

\begin{tabular}{ccccccccc}
\hline Soil & $\begin{array}{c}\text { Clay } \\
(\%)\end{array}$ & $\begin{array}{c}\text { Silt } \\
(\%)\end{array}$ & $\begin{array}{c}\text { Sand } \\
(\%)\end{array}$ & $\begin{array}{c}\text { Texture } \\
\text { Class }\end{array}$ & $\begin{array}{c}\text { Organic } \\
\text { matter } \\
(\%)\end{array}$ & $\begin{array}{c}\mathrm{CaCO}_{3} \\
(\%)\end{array}$ & $\mathrm{pH}$ & $\begin{array}{c}\mathrm{EC} \\
\left(\mathrm{dS} \mathrm{m}^{-1}\right)\end{array}$ \\
\hline Soil & 42.51 & 39.45 & 18.04 & $\mathrm{C}$ & 1.55 & 24.1 & 7.44 & 0.34 \\
$0-10 \mathrm{~cm}$ & 41.29 & 39.99 & 18.72 & $\mathrm{C}$ & 1.56 & 24.2 & 7.38 & 0.38 \\
$10-20 \mathrm{~cm}$ & - & - & - & - & 45.10 & - & 7.70 & 3.58 \\
\hline FYM & - & & & & & & &
\end{tabular}


Bulk density was determined in undisturbed soil samples taken by steel cylinders (Blake and Hartge, 1986). Soil moisture contents were determined in undisturbed soil samples at 0.001, 0.1, 0.33 (field capacity) and 1.0 bar whereas 5, 10 and 15 bars (wilting point) moisture contents were determined in disturbed soil samples for soil water characteristics (Klute, 1986). The available water content of soil was calculated from the difference in the moisture content between 0.33 and 15 bars (Klute, 1986). The total porosity was determined from the water content of saturated soil and the micro porosity was volumetric field capacity. Macro porosity was calculated by taking the difference between total porosity and microporosity (Danielson and Sutherland, 1986). A hydrometer method was used to determine textural fractions (Bouyoucos, 1962). Organic matter content was determined by using modified Walkley-Black wet oxidation method and dry ashing method (at $400^{\circ} \mathrm{C}$ for $16 \mathrm{~h}$ in an oven) for soil and FYM, respectively (Burt, 2004). Soil pH and electrical conductivity (EC) were measured in a 1:1 soilto-distilled water suspension, whereas $\mathrm{pH}$ and EC of FYM were determined in a 1:2.5 FYM-to-distilled water suspension (Burt, 2004). Calcium carbonate equivalent was determined by a volumetric method using a Scheibler calcimeter (Kacar, 2009).

The statistical analysis was performed by using Minitab-16 software program. The standard ANOVA procedures were subjected to the data-sets and the homogenous sub-sets were separated by Tukey test at $\mathrm{P}<0.05$.

\section{Results and Discussion}

\subsection{Bulk density}

The effects of FYM and GM applications were given in Table 2 on soil bulk density. The highest bulk density value $\left(1.30 \mathrm{~g} \mathrm{~cm}^{-3}\right)$ was obtained in the $\mathrm{C}$ application. The bulk density values were $1.22 \mathrm{~g}$ $\mathrm{cm}^{-3}$ and $1.17 \mathrm{~g} \mathrm{~cm}^{-3}$ for the GM and FYM applications, respectively. Statistically significant differences were obtained to among the applications. Yeşilsoy and Aydın (1993) stated that the bulk density value of a typical clay soil may be below $1.1 \mathrm{~g} \mathrm{~cm}^{-3}$. Abdelbaki (2018) stated that there was a significant negative correlation between bulk density and organic carbon. The bulk density of soils can better response to long term organic material incorporations (Haynes and Naidu, 1998). It statistical effects on the soil bulk density were apparent as organic matter repeatedly applied in many years (Table 2).

Table 2. The Effects of FYM and GM applications on soil bulk density $\left(\mathrm{g} \mathrm{cm}^{-3}\right)$

\begin{tabular}{cllccccc}
\hline & \multicolumn{2}{c}{$1^{\text {st }}$ year } & \multicolumn{3}{c}{$2^{\text {nd }}$ year } \\
\hline & $0-10 \mathrm{~cm}$ & $10-20 \mathrm{~cm}$ & $\mathrm{Y}^{*} \mathrm{~A}$ & $0-10 \mathrm{~cm}$ & $10-20 \mathrm{~cm}$ & $\mathrm{Y}^{*} \mathrm{~A}$ & $\mathrm{~A}$ \\
\hline $\mathrm{C}$ & 1.27 & 1.33 & $1.30 a^{* *}$ & 1.28 & 1.33 & $1.30 a$ & $1.30 \mathrm{~A}^{* * *}$ \\
FYM & 1.13 & 1.23 & $1.18 d$ & 1.10 & 1.20 & $1.15 e$ & $1.17 \mathrm{C}$ \\
$\mathrm{GM}$ & 1.21 & 1.26 & $1.24 b$ & 1.18 & 1.24 & $1.21 c$ & $1.22 \mathrm{~B}$ \\
Y*D & $1.20 \mathrm{c}$ & $1.28 \mathrm{a}^{*}$ & & $1.19 \mathrm{~d}$ & $1.26 \mathrm{~b}$ & \\
\hline Variation Source & $\mathrm{F}$ & $\mathrm{P}$ & Variation Source & $\mathrm{F}$ & $\mathrm{P}$ & \\
\hline Year(Y) & 36.32 & 0.000 & YxA & 12.18 & 0.000 & \\
Application (A) & 793.97 & 0.000 & YxD & 0.40 & 0.533 & \\
Depth(D) & 652.95 & 0.000 & AxD & 36.33 & 0.000 & \\
& & & YxAxD & 0.82 & 0.453 & \\
\hline
\end{tabular}

* Lowercase letters indicated interaction between $\mathrm{Y}$ and D

** Italic letters indicated interaction between $\mathrm{Y}$ and $\mathrm{A}$

*** Capital letters indicated the effects of applications

In the first year (2012) average bulk density was $1.24 \mathrm{~g} \mathrm{~cm}^{-3}$, while the second year (2013) it decreased to $1.22 \mathrm{~g} \mathrm{~cm}^{-3}$. Continuous addition of organic matter, good crop rotation and reduced soil tillage practices could provide the desired bulk density (Tsadilas et al., 2005; Mujdeci et al., 2017b). Mujdeci et al., (2017a) stated that farmyard manure and biosolid applications reduced the soil bulk density. A good soil structure is essential for sustainable crop production and bulk density is an important indicator of soil structure (Xu and Zhang, 2004). The low organic matter content of the study area (Table 1) enabled to a rapid response to the applied organic materials. On the other hand, the properties of the added organic material were also important for improving bulk density (Mujdeci et al., 2017b). The soil bulk density values were lower in the surface layer $\left(0-10 \mathrm{~cm}, 1.19 \mathrm{~g} \mathrm{~cm}^{-3}\right)$ than the sub 
surface $\left(10-20 \mathrm{~cm}, 1.27 \mathrm{~g} \mathrm{~cm}^{-3}\right)$. Although the soil was cultivated at a depth of about $20-25 \mathrm{~cm}$, the organic material in the surface layer was relatively high due to the stimulating environment for microbial activity in the surface layer that acted in favour of reducing the bulk density (Shi et al., 2013; Mujdeci et al., 2017b). Organic matter treatments increased the pore ratio in the surface soil and thus the bulk density reduced. Organic matter is lower density than soil. In general, the higher organic matter means the lower soil bulk density (Hossain et al., 2015). It was reported that the organic matter treatments cause a depth-dependent organic matter increase in the soils and thus soil bulk density decrease (Mujdeci et al., 2017b).

\subsection{Soil water characteristics}

The effects of FYM and GM applications on the soil water characteristics (0.001, 0.1, 0.33, 1 , 5, 10 and 15 bar) were given in Table 3 . The main effects and interactions were statistically significant at all pressures, except for YxD and YxAxD interactions at 1, 5 and 15 bar $(\mathrm{P}<0.01)$. The highest volumetric water content was found in the FYM application at all pressures. The lowest values were obtained in the $C$ treatment. FYM and GM applications caused a change in water content at all pressures. Similarly, Mujdeci et al. (2017a) investigated the effects of different cultural practices (soil tillage, farmyard manure and biosolid) on soil water characteristics (0.001, 0.1, 0.33, 1, 5, 10 and 15 bar). They found the highest volumetric water contents in the FYM applications at all pressures. Barzegar et al. (2002) stated that organic materials increased the amount of water held at a potential below $100 \mathrm{kPa}$.

Table 3. The results of variance analysis on the effects of FYM and GM applications on soil water characteristics and available water content

\begin{tabular}{|c|c|c|c|c|c|c|c|}
\hline Bar & Variation Source & $\mathrm{F}$ & $\mathrm{P}$ & Bar & Variation Source & $\mathrm{F}$ & $\mathrm{P}$ \\
\hline \multirow{7}{*}{0.001} & $\mathrm{Y}$ & 1012.61 & 0.000 & \multirow{7}{*}{5} & $\mathrm{Y}$ & 658.68 & 0.000 \\
\hline & A & 14728.04 & 0.000 & & A & 4067.12 & 0.000 \\
\hline & D & 19413.34 & 0.000 & & D & 1783.26 & 0.000 \\
\hline & YxA & 252.13 & 0.000 & & YxA & 173.85 & 0.000 \\
\hline & $\mathrm{YxD}$ & 7.00 & 0.014 & & YxD & 3.95 & 0.058 \\
\hline & $\mathrm{AxD}$ & 347.96 & 0.000 & & $\mathrm{AxD}$ & 5.72 & 0.009 \\
\hline & YxAxD & 5.70 & 0.009 & & YxAxD & 2.06 & 0.150 \\
\hline \multirow{7}{*}{0.1} & $\mathrm{Y}$ & 901.47 & 0.000 & \multirow{7}{*}{10} & $\mathrm{Y}$ & 1086.13 & 0.000 \\
\hline & A & 5721.04 & 0.000 & & A & 6539.07 & 0.000 \\
\hline & D & 4821.48 & 0.000 & & $\mathrm{D}$ & 3833.17 & 0.000 \\
\hline & YxA & 226.64 & 0.000 & & YxA & 281.28 & 0.000 \\
\hline & $\mathrm{YxD}$ & 6.64 & 0.017 & & YxD & 4.94 & 0.036 \\
\hline & $\mathrm{AxD}$ & 65.90 & 0.000 & & $\mathrm{AxD}$ & 7.82 & 0.002 \\
\hline & YxAxD & 9.87 & 0.001 & & YxAxD & 1.48 & 0.247 \\
\hline \multirow{7}{*}{0.33} & $\mathrm{Y}$ & 440.55 & 0.000 & \multirow{7}{*}{15} & $\mathrm{Y}$ & 698.69 & 0.000 \\
\hline & A & 2725.65 & 0.000 & & A & 3975.25 & 0.000 \\
\hline & D & 555.28 & 0.000 & & $\mathrm{D}$ & 1581.73 & 0.000 \\
\hline & YxA & 107.32 & 0.000 & & YxA & 183.05 & 0.000 \\
\hline & $\mathrm{YxD}$ & 13.74 & 0.001 & & YxD & 0.34 & 0.565 \\
\hline & $\mathrm{AxD}$ & 256.50 & 0.000 & & $A x D$ & 20.85 & 0.000 \\
\hline & YxAxD & 4.74 & 0.018 & & YxAxD & 0.69 & 0.512 \\
\hline \multirow{7}{*}{1} & $\mathrm{Y}$ & 617.59 & 0.000 & \multirow{7}{*}{ AWC } & $\mathrm{Y}$ & 0.02 & 0.883 \\
\hline & A & 5186.73 & 0.000 & & A & 3.19 & 0.059 \\
\hline & D & 1891.84 & 0.000 & & $\mathrm{D}$ & 40.36 & 0.000 \\
\hline & YxA & 156.99 & 0.000 & & YxA & 7.83 & 0.002 \\
\hline & YxD & 1.44 & 0.243 & & YxD & 6.13 & 0.021 \\
\hline & $\mathrm{AxD}$ & 7.53 & 0.003 & & $\mathrm{AxD}$ & 100.56 & 0.000 \\
\hline & YxAxD & 1.03 & 0.373 & & YxAxD & 1.85 & 0.179 \\
\hline
\end{tabular}

Year (Y), Applications (A), Depth (D), Available water content (AWC)

With the addition of long-term organic material, the soil bulk density decreases while the water retention capacity, porosity, infiltration capacity and aggregation increase (Haynes and Naidu, 1998). Mujdeci and Uzumcu (2017) found that farmyard manure and green manure applications increased soil aggregation and aggregate size. In this study, changes in water holding capacity depending on applications $2^{\text {nd }}$ year were more prominent (Figure 1). 


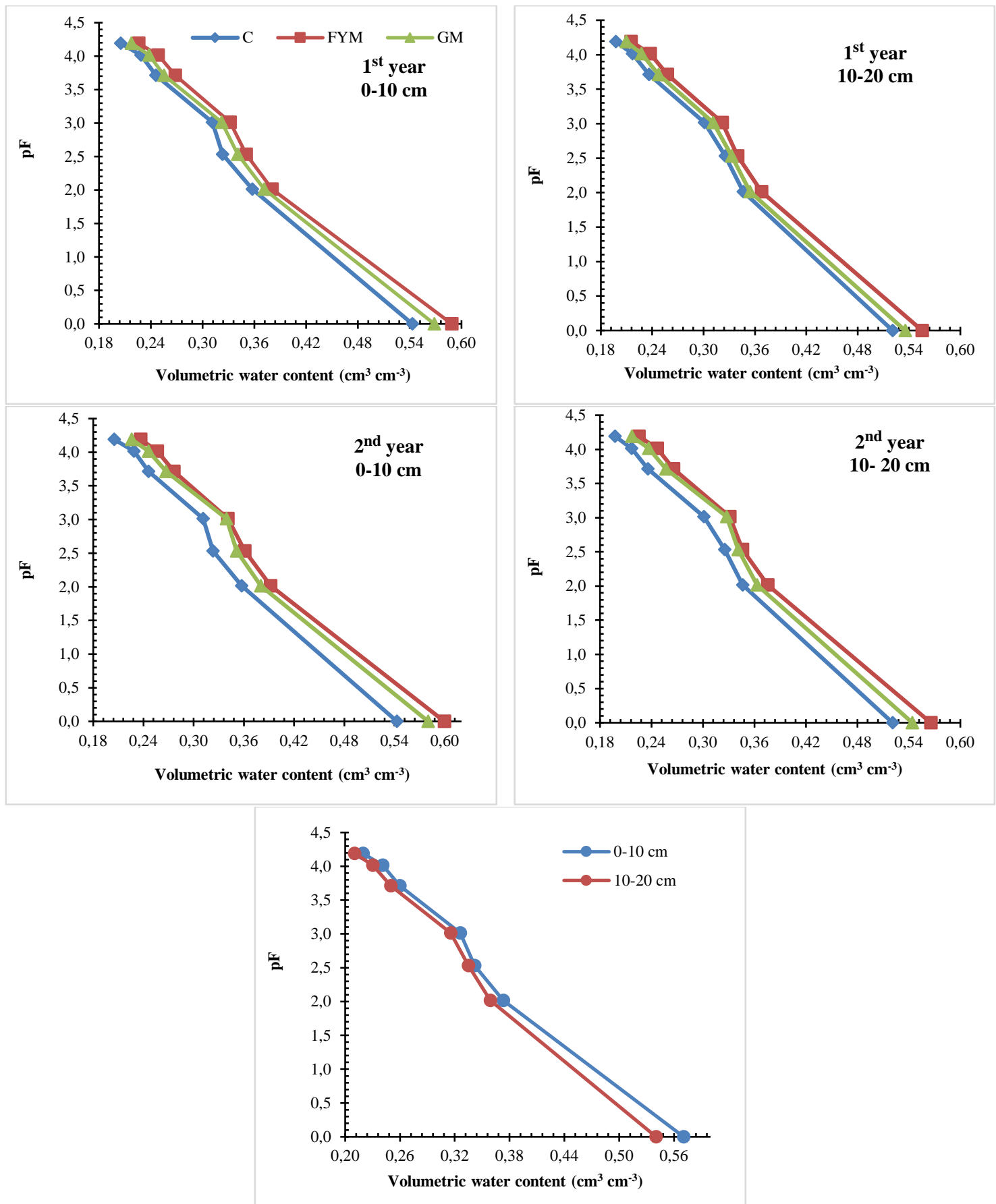

Figure 1. The Effects of FYM and GM applications on soil water characteristics.

Similarly, many researchers stated that organic material applications increased soil water retention capacities (Tsadilas et al., 2005; Tadesse et al., 2013; Alaboz et al., 2017; Mujdeci et al., 2017a). The higher volumetric water contents were obtained on surface soil $(0-10 \mathrm{~cm})$ at all pressures in question (Figure 1). This is due to the relative excess of organic matter in the surface layer. It was clear that organic matter was more effective in increasing water retention properties (Y1lmaz and Alagöz, 2008). The field capacity and wilting point vary depending on the texture, organic matter, structure, clay content, etc. (Karahan et al., 2014).

The effects of FYM and GM applications on the field capacity, wilting point and available water content were given in Figure 2. The field capacity was between 0.323 and $0.361 \mathrm{~cm}^{3} \mathrm{~cm}^{-3}$, the wilting point was between 0.197 and $0.126 \mathrm{~cm}^{3} \mathrm{~cm}^{-3}$. Available water content range was $0.118-0.126 \mathrm{~cm}^{3} \mathrm{~cm}^{-3}$. Diallo and Mariko (2013) stated that the field capacity and wilting point moisture levels were reported in the range of $16.01-45.90,3.95-27.10 \%$, respectively, on clay soils. FYM and GM applications 
resulted in increasing wilting point and field capacity. So, when the change was about the same ratio (Haynes and Naidu, 1998), the difference was found non-significant in the available water content. Since the soil has clayey texture, the effect of organic matter treatments remained trivial. Therefore, the effects of organic materials to a specific soil was highly dependent on the properties, frequency and amount of organic materials added and other environmental factors (Moraes et al., 2016; Pires et al., 2017; Sandin et al., 2017).

Depending on the soil depth, the effects of organic material treatments on the available water content became important $(\mathrm{P}<0.01)$. The available water content of surface layer $\left(0.122 \mathrm{~cm}^{3} \mathrm{~cm}^{-3}\right)$ was lower than the sub-surface one $\left(0.125 \mathrm{~cm}^{3} \mathrm{~cm}^{-3}\right)$. The main effect of years was non-significant (Table $3)$.

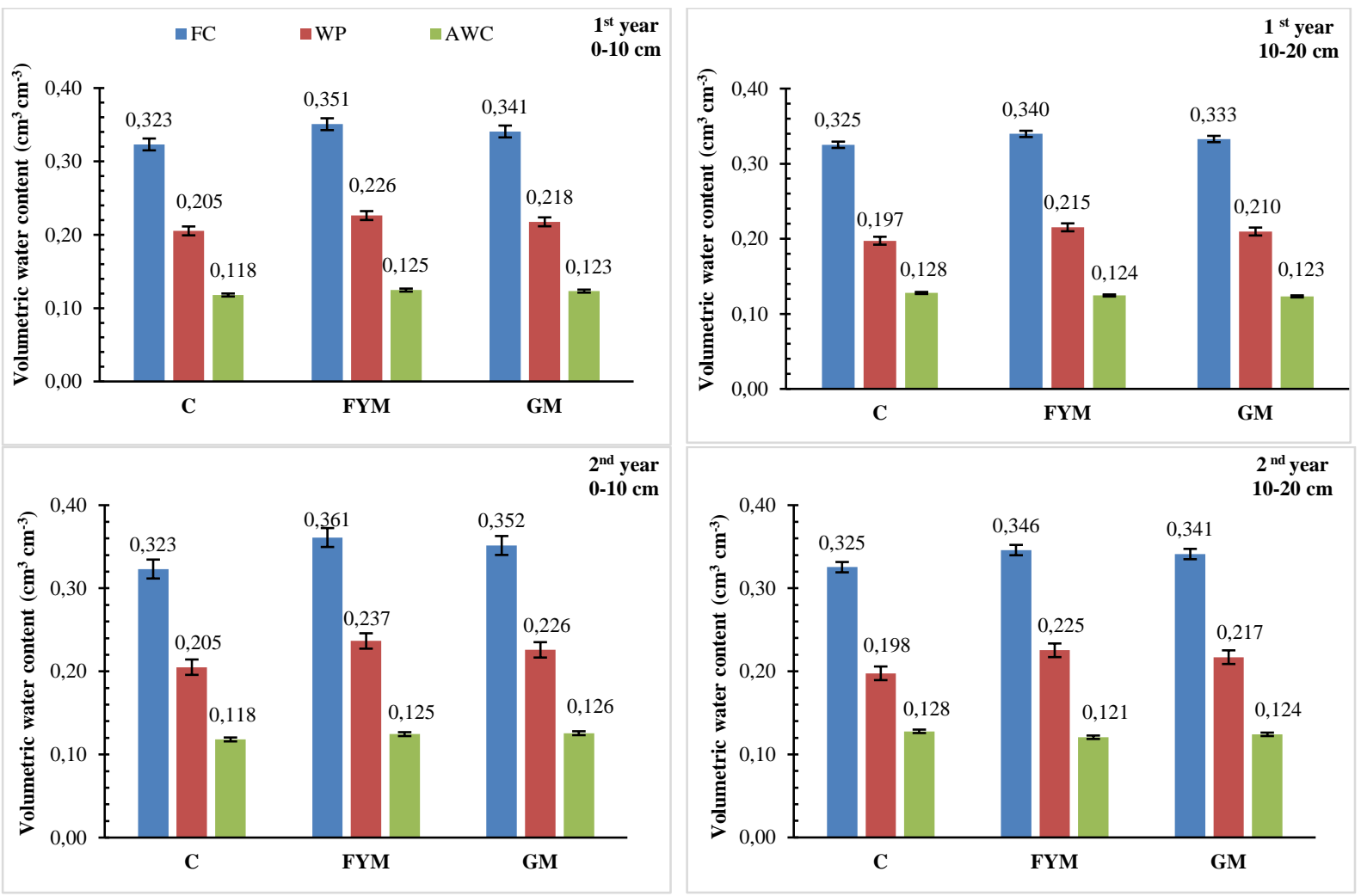

Figure 2. The Effects of FYM and GM applications on soil field capacity, wilting point and available water content.

\subsection{Porosity}

The effects of FYM and GM applications on soil porosity were given in Table 4. All main effects and interactions were significant for total, macro and micro porosity except for $\mathrm{YxA}, \mathrm{YxD}$ and $\mathrm{YxAxD}$ interactions for macro porosity $(\mathrm{P}<0.05)$.

Table 4. The effects of FYM and GM applications on porosity

\begin{tabular}{lcccccc}
\hline & \multicolumn{2}{c}{ Macro porosity } & \multicolumn{2}{c}{ Micro porosity } & \multicolumn{2}{c}{ Total porosity } \\
\hline & $\mathrm{F}$ & $\mathrm{P}$ & $\mathrm{F}$ & $\mathrm{P}$ & $\mathrm{F}$ & $\mathrm{P}$ \\
\hline $\mathrm{Y}$ & 5.24 & 0.031 & 440.55 & 0.000 & 1012.61 & 0.000 \\
$\mathrm{~A}$ & 888.84 & 0.000 & 2725.65 & 0.000 & 14728.04 & 0.000 \\
$\mathrm{D}$ & 3509.59 & 0.000 & 555.28 & 0.000 & 19413.34 & 0.000 \\
$\mathrm{Y} * \mathrm{~A}$ & 2.84 & 0.078 & 107.32 & 0.000 & 252.13 & 0.000 \\
$\mathrm{Y} * \mathrm{D}$ & 1.49 & 0.233 & 13.74 & 0.001 & 7.00 & 0.014 \\
$\mathrm{~A} * \mathrm{D}$ & 13.32 & 0.000 & 256.50 & 0.000 & 347.96 & 0.000 \\
$\mathrm{Y} * \mathrm{~A} * \mathrm{D}$ & 2.86 & 0.077 & 4.74 & 0.018 & 5.70 & 0.009 \\
\hline $\mathrm{Y}:$ year, A: applications, D: depth & & & & & \\
\hline
\end{tabular}


The macro porosity of the soil ranged from 0.195 to $0.238 \mathrm{~cm}^{3} \mathrm{~cm}^{-3}$, while the micro porosity was determined between $0.323-0.361 \mathrm{~cm}^{3} \mathrm{~cm}^{-3}$. Total porosity has a minimum of $0.520 \mathrm{~cm}^{3} \mathrm{~cm}^{-3}$ and a maximum of $0.599 \mathrm{~cm}^{3} \mathrm{~cm}^{-3}$. The total, macro and micro porosity of the soil were found to be the highest in FYM application and the lowest in C application (Figure 3). FYM and GM applications were caused changes in total, macro and micro porosity. However, the changes were more pronounced in the second year.
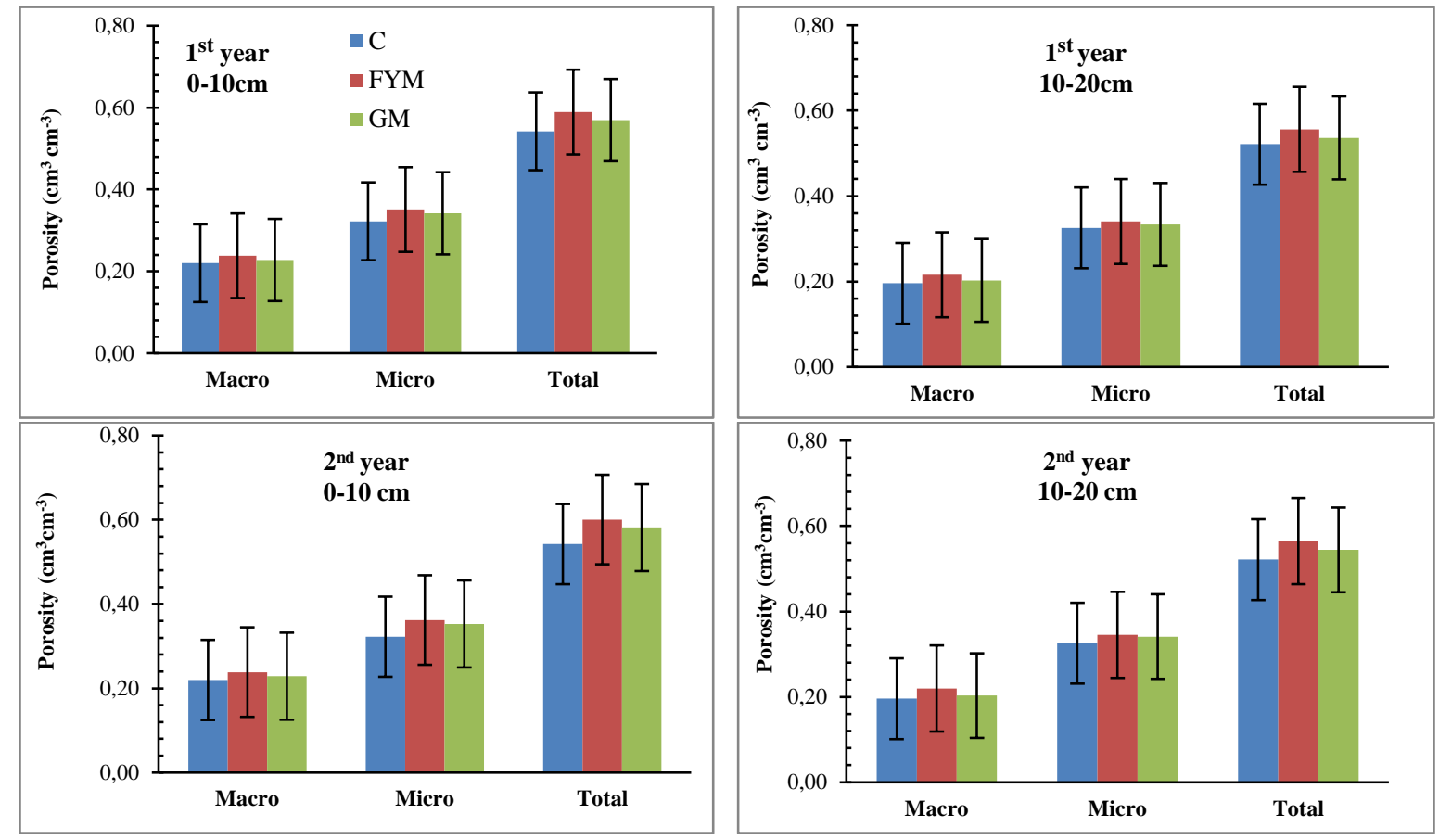

Figure 3. The effects of FYM and GM applications on total, macro and micro porosity.

Mujdeci et al. (2017a) stated that farmyard manure and biosolid applications increased total porosity and micro porosity. Variation of the applications depending on soil depth was found to be statistically significant. Total, macro and micro porosity in the upper soil layer $(0-10 \mathrm{~cm})$ was higher than the underlying soil $(10-20 \mathrm{~cm})$ (Figure 3$)$. Total, macro and micro porosity were found to be the highest in the FYM application at both depths, while the lowest values were obtained in the C application (Figure 3). The applications provided more organic matter to surface soil and therefore, the effect of organic materials on soil porosity was found to be higher at $0-10 \mathrm{~cm}$. In the study, the effect of the applications was found to be significant depending on the years. In second year, the highest total, macro and micro porosity were determined in the FYM application. Since fine textured soils have a large number of micro porosity, their water retention properties are high. The GM application was lower in all depths and years than FYM. It has higher macro, micro and total porosity compared to control. This is due to the organic material content of the soil after application. Organic material contents of GM applied soil were lower than FYM (Mujdeci et al., 2017b).

\section{Conclusions}

In this study, the depth-dependent-effects of FYM and GM applications on some soil physical properties (soil water characteristics (0.001. 0.1. 0.33. 1. 5.10 and 15 bars), available water content, porosity and bulk density) were investigated. The highest volumetric soil water content was obtained in FYM application and the lowest volumetric soil water content was obtained in C application in all pressure. Field capacity and wilting point increased depending on FYM and GM application. Available water content also increased. However, the effects of applications on available water content were not statistically significant. The effects of applications on porosity and bulk density were found to be statistically significant. Total, macro and micro porosity were found as the highest in the FYM application, the lowest in the C application. The FYM application was found to be more effective in 
improving soil physical properties in all investigated properties. As a result, there may be differences in soil physical properties according to the applied materials. In order to have more pronounced effects of organic matter applications, yearly or repeated incorporation of organic matter is suggested.

\section{Acknowledgements}

This study was financially supported by the Scientific Research Foundation of Süleyman Demirel University as a MSc thesis with project number of 3093-YL-12. The paper was partially presented at the $8^{\text {th }}$ International Conference of Strategic Research on Scientific Studies and Education, Vienna/Austria and published as an abstract.

\section{References}

Abdelbaki, A. M. (2018). Evaluation of Pedotransfer functions for predicting soil bulk density for US soils. Ain Shams Engineering Journal, 9, 1611-1619.

Alaboz, P., Coskan, A., \& Işıldar, A. A. (2017). Effect of saw-dust biochar on some soil moisture constants. Fresenius Environmental Bulletin, 26(6), 4033-4038.

Alaboz, P., Işıldar, A. A., Müjdeci, M., \& Şenol, H. (2017a). Effects of different vermicompost and soil moisture levels on pepper (Capsicum annuum) grown and some soil properties. Yüzüncü Yll Üniversitesi Tarım Bilimleri Dergisi, 27(1), 30-36.

Alagöz, Z., Yılmaz, E., \& Öktüren, F. (2006). Effects of Organic material addition on some physical and chemical properties of soils. Akdeniz Üniv. Ziraat Fakültesi Dergisi, 19(2), 245-254.

Altıkat, S., Küçükerdem, H. K., \& Altıkat, A. (2018). Effects of wheel traffic and farmyard manure applications on soil $\mathrm{CO}_{2}$ emission and soil oxygen content. Turkish Journal of Agriculture and Forestry, 42, 288-297.

Barzegar, A. R., Yousefi, A., \& Daryashenas, A. (2002). The effect of addition of different amounts and types of organic materials on soil physical properties and yield of wheat. Plant and Soil, 247, 295-301.

Bellitürk, K. (2011). Determination of nutrient status of agricultural soils in uzunkopru county of Edirne province. Tekirdağ Ziraat Fakültesi Dergisi, 8(3), 8-15.

Blake, G. R., \& Hartge, K. H. (1986). Physical and Mineralogical Methods. In: A. Klute (Ed), Methods of Soil Analysis (pp. 363-375) Part 1 Agr. Monogr. 9. ASA and SSSA Madison WI.

Bouyoucos, G.J. (1962) Hydrometer method improved for making particle size analyses of soils. Agron. J. 54, 464-465.

Burt, R. (Ed.) (2004) Soil Survey Laboratory Methods Manual, Soil Survey Investigations Rep. 42, version 4.0, USDA-NRCS.

Danielson, R. E. \& Sutherland, P. L., (1986). Porosity, in: Methods of Soil Analysis, Part 1, Physical and Mineralogical Methods, $2^{\text {nd }}$ Edn., edited by: Klute, A., Agron. Monogr. 9., ASA and SSSA, Madison WI., USA, 443-461.

Diallo, D., \& Mariko, A., (2013). Field capacity (FC) and permanent wilty point (PWP) of clay soils developed on quaternary alluvium in nigerriver loop (Mali). International Journal of Engineering Science, 3, 1085-1089.

Eyüpoğlu, F. (1999). Türkiye Topraklarının Verimlilik Durumu. Ankara: Başbakanlık Köy Hizmetleri Genel Müdürlüğü Toprak Ve Gübre Araştırma Enstitüsü Müdürlüğü Yayınları.

Gulser, C., \& Candemir, F. (2012). Changes in penetration resistance of a clay field with organic waste applications. Eurasian Journal of Soil Science, 1, 16-21.

Haynes, R. J., \& Naidu, R. (1998). Influence of lime, fertilizer and manure applications on soil organic matter content and soil physical conditions, A review Nutrient Cycling in Agroecosystems, 51, 123-137.

Hossain, M. F., Chen, W., \& Zhang, Y. (2015). Bulk density of mineral and organic soils in the Canada's arctic and sub-arctic. Information Processing in Agriculture, 2(3-4), 183-190.

Kacar, B. (2009). Toprak Analizleri. Ankara: Nobel Yayınları.

Karahan, G., Erşahin, S., \& Öztürk, H. S. (2014). Field capacity dynamics affected by soil properties. Gaziosmanpaşa Üniversitesi Ziraat Fakültesi Dergisi, 30(1), 1-9. 
Karaman, M. R., Brohi, A. R., Müftüoğlu, N. M., Öztaş, T., \& Zengin, M. (2007). Sürdürülebilir Toprak Verimliliği. Ankara: Detay Yayıncılık.

Klute, A. (1986). Water Retention: Laboratory Methods. In: Methods of Soil Analysis, Part 1, Physical and Mineralogical Methods. (Ed: A. Klute) Agr. Monogr.). ASA and SSSA Madison WI, 635662.

Moraes, M. T., Debiasi, H., Carlesso, R., Franchini, J. C., da Silva, V. R., \& da Luz, F. B. (2016). Soil physical quality on tillage and cropping systems after two decades in the subtropical region of Brazil. Soil \& Tillage Research, 155, 351-362.

Mujdeci, M., Isildar, A. A., Uygur, V., Alaboz, P., Unlu, H., \& Senol, H. (2017b). Cooperative effects of field traffic and organic matter treatments on some compaction-related soil properties. Solid Earth, 8, 189-198.

Mujdeci, M., Simsek, S., \& Uygur, V. (2017a). The effects of organic amendments on soil water retention characteristics under conventional tillage system. Fresenius Environmental Bulletin, 26(6), 4075-4081.

Mujdeci, M., \& Uzumcu, E. (2017). The effects of farmyard manure and greenmanure applications on soil aggregation. Fresenius Environmental Bulletin, 26(5), 3692-3696.

Özbek, H., Kaya, Z., Gök, M., \& Kaptan, H. (1995). Toprak Bilimi. Adana: Çukurova Üniversitesi Ziraat Fakültesi Genel Yayınları.

Pires, L. F., Borgesa, J. A. R., Rosab, J. A., Cooperc, M., Heckd, R. J., Passonia, S., \& Roquee, W. L. (2017). Soil structure changes induced by tillage systems. Soil \& Tillage Research, 165, 66-79.

Rowell, D. L. (1996). Soil Science, Methods and Applications. U.K: University of Reading, British Library Catalogue in Publication data.

Sandin, M., Koestel, J., Jarvis, N., \& Larsbo, M. (2017). Post-tillage evolution of structural pore space and saturated and near-saturated hydraulic conductivity in a clay loam soil. Soil \& Tillage Research, 165, 161-168.

Shi, Y., Lalande, R., Hamel, C., Ziadi, N., Gagnon, B., \& Hu, Z. (2013). Seasonal variation of microbial biomass, activity, and community structure in soil under different tillage and phosphorus management practices. Biology and Fertility of Soils, 49, 803-818.

Tadesse, T., Dechassa, N., Bayu, W., \& Gebeyehu, S. (2013). Effects of farmyard manure and inorganic fertilizer application on soil physico-chemical properties and nutrient balance in rain-fed lowland rice ecosystem. American Journal of Plant Sciences, 4, 309-316.

Tsadilas, C. D., Mitsios, I. K., \& Golia, E. (2005). Influence of biosolids application on some soil physical properties. Communications in Soil Science and Plant Analysis, 36, 709-716.

Turan, M. A., Katkat, A.V., Özsoy, G., \& Taban, S. (2010). Determination of fertility condition and potential nutrition problems of aluvial agriculture soils in Bursa region. Uludağ Üniversitesi Ziraat Fakültesi Dergisi, 24(1), 115-130.

Tümsavaş, Z. (2003). Determination of the fertility levels of the soils of vertisol great soil group by soil analysis in bursa province. Uludağ Üniversitesi Ziraat Fakültesi Dergisi, 17(2), 9-21.

Üzümcü, E. (2016). Çiftlik Gübresi ve Yeşil Gübre Uygulamalarının Toprak Agregasyonu Üzerine Etkileri. Süleyman Demirel Üniversitesi Fen Bilimleri Enstitüsü Toprak Bilimi ve Bitki Besleme Anabilim Dalı Yüksek Lisans Tezi 34 sayfa, Isparta.

Xu, X., \& Zhang, J. (2004). Effect of sown grass and organism mulching on orchard soil fertility. Journal of Sichuan Agricultural University, 22(1), 88-91.

Yeşilsoy, M. Ş. \& Aydın, M. (1993). Toprak Fiziği. Adana: Çukurova Üniversitesi Ziraat Fakültesi Ders Kitabi: 124

Yılmaz, E., \& Alagöz, Z. (2008). Organik Madde Toprak Suyu İlişkisi. Türk Bilimsel Derlemeler Dergisi, 1(2), 15-21. 